ISBN - 978-93-86878-38-0

22nd ISTANBUL International Conference on Ecological Agriculture, Biodiversity and Internal

Diseases (EABID-20)

Istanbul (Turkey) March 2-4, 2020

\title{
Genotypic Variation of Peanut Plant (Arachis hypogaea L.) in Response to Iron Deficiency in Calcareous Soil
}

\author{
Bülent TOPCUOĞLU ${ }^{1}$ \\ ${ }^{1}$ Akdeniz University Vocational School of Technical Sciences 07058 Antalya TURKEY
}

\begin{abstract}
A field experiment has been carried out to study genotypic variation for resistance to iron (Fe) deficiency in calcareous soils. The experiment was conducted in loam texture, calcareous with a slightly alkaline reaction soil. In order to explore the variability of Fe use efficiency of sixteen Peanut lines (Osmaniye, Gazipasa, $I C G V-88463$, ICGV-88172, ICGV-88490, ICGV-88398, NC-7, GK-3, COM, Florigant, Anamur-K, Cine, PI346385, Edirne9P-53, Adana-Selection, PI-372317) commenly cultured in Turkey were cultivated under field conditions. Experimental soil characteristics, differences of total chlorophyll and total and active Fe contents among varieties were analysed. Fe-deficiency-induced-chlorosis on young leaves was earlier and more severe in some varieties than others. The new line ICGV-88463 and local variety Gazipassa contained higher total chlorophyll and active Fe and showed no deficiency symptoms than the other lines. As for COM, Florigant, Anamur-K, ICGV-88490, PI-346385 varieties have moderate level of active Fe and total chlorophyll content. There was a linear correlation between total chlorophyll and active Fe among the varieties. It can be concluded that due to high Fe use efficiency, ICGV-88463 and Gazipassa varieties could be succesfully cultuvated on calcereous soils, and Fe use efficiency for Peanut could be used to screen tolerant Peanut varieties to Fe deficiency. Application of these data in future studies has potential utility within the fields of agro-biodiversity conservation and nutrition of Peanut.
\end{abstract}

Keywords: Peanut; Fe Deficiency; Fe Use Efficiency; Genotypic Variability

\section{Introduction}

Peanut (Arachis hypogaea L.), a major oilseed crop is cultivated predominantly under rain-fed conditions in the semi-arid tropics. The iron (Fe) concentration in the earth's crust varies from $200 \mathrm{ppm}$ to more than $10 \%$. However, Fe is almost exclusively present in the soil in its oxidised to form Fe+3 (III). The availability of Fe+3 for plant nutrition is quite limited because of its very low solubility. In calcareous soils which constitute more than $30 \%$ of the planet's cultivated land, the soil solution does not provide more than $10 \%$ of the plant requirements for $\mathrm{Fe}$ [1]. Fe is known to be essential for many physiological and biochemical prosesses in plant metabolism such as: photosynthesis, respiration, DNA synthesis and N2 fixation.

In calcareous soils, the yield of Peanut is often limited by the lower availability of Fe. It is known that there are a wide range of differences among species and genotypes in plant response to Fe deficiency. Peanut seed yields decreased when grow on calcareous soil, and Fe chlorosis was noticed in soils containing 5-20 \% $\mathrm{CaCO} 3$ and increased with increasing $\mathrm{CaCO} 3$ rate [2]. Fe use efficiency (IUE) of plant may be one such trait that can contribute to productivity when Fe availability are limited. Differences among species and genotypes in plant response to Fe deficiency have been reported [3]. The exploration of genotypic variability in the responses of Peanut to Fe deficiency may allow identification of physiological or biochemical tools to screen tolerant varieties and to improve the productivity of this crop in calcareous soils. 
Therefore, the development of Fe deficiency resistant cultivars of Peanut has been assumed considerable importance. Conventional breeding approaches based on yield as a sole criterion is proving to be insufficient in achieving gains to problematic soil conditions. It has postulated that it would be more efficient and successful to attempt improving growth and yield per resource use rather than selecting for yield alone [4]. Fe deficiency tolerance may be one such trait that can contribute to productivity when Fe availability are limited by soil $\mathrm{CaCO} 3$.

The aim of this study is to determine the efficiency of iron use by field trial of Peanut genotypes grown under calcareous alkaline soil conditions.

\section{Materials and Methods}

\subsection{Experimental Site and Soil Analysis}

A field experiment has been carried out to study genotypic variation for tolerance to Fe deficiency in calcareous soils. The experiment was conducted from 1997 to 1998 on experimental fields of West Mediterranean Agricultural Research Institute (former Mediterranean Agricultural Research Institute) experimental fields, representative of the major Peanut-growing areas of Antalya $\left(36^{\circ} 56^{\prime} \quad 28 \mathrm{~N}\right.$ latitude and $30^{\circ} 53^{\prime} 21 \mathrm{E}$ longitude), in loaming, calcareous soils with a slightly alkaline reaction. The geological materials of study area are mainly of calcareous nature with average $12 \mathrm{~m}$ altitude. The land is influenced by a Mediterranean climate with a high average annual rainfall $(1100 \mathrm{~mm} / \mathrm{year})$, the annual average temperature being around $18,2{ }^{\circ} \mathrm{C}, 63 \%$ average humidity and average 149 sunny days per year.

Field soil samples were taken at a depths of 0 to $30 \mathrm{~cm}$ and $30-60 \mathrm{~cm}$, and these samples were air-dried, sieved $(<2 \mathrm{~mm})$ and stored in polyethylene bags sealed awaiting analysis. Electrical conductivity (EC) and $\mathrm{pH}$ were measured a soil: water ratio of 1:2. cation exchange capacity (CEC) was determined by $0.1 \mathrm{M}$ NN4AoC extraction; $\mathrm{CaCO} 3$ content was determined by the calcimeter; free $\mathrm{CaCO} 3$ and water soluble $\mathrm{HCO} 3$ were determined by titration method; organic carbon was measured by wet oxidation; and texture was determined by Bouyoucos hydrometer method. Total nitrogen was determined by kjeldahl method, available phosphorus was determined by Olsen ( $\mathrm{pH} \mathrm{8,5)} \mathrm{method;} \mathrm{exchangeable} \mathrm{potassium,} \mathrm{calcium} \mathrm{and} \mathrm{magnesium} \mathrm{were} \mathrm{determined} \mathrm{by}$ ammniumacetate extraction method. Bioavailable fractions of metals were extracted from soil with diethylenetriaminepentaacetic acid-CaCl2-triethanolamine adjusted to $\mathrm{pH} 7.3$ (DTPA) procedure. Extracted element concentrations were analysed using ICP-MS under optimised measurement conditions, and values were adjusted for oven dried $\left(12 \mathrm{~h}\right.$ at $\left.105^{\circ} \mathrm{C}\right)$ material. All analysis of the mentioned chemical and pyhical properties of soil was carried out by using Standard methods [5].

\subsection{Field Experiment and Plant Analysis}

A randomized complete block design was used each year with six replications. Plots consisted of two rows $6.1 \mathrm{~m}$ long x $1.9 \mathrm{~m}$ wide. Seeds of 16 Peanut genotypes (Arachis hypogaea L.) were obtained from West Mediterranean Agricultural Research Institute, Antalya Turkey. Peanut seeds were spaced approximately $5 \mathrm{~cm}$ apart within each row. Planting dates were the first week of May 1997. During the experiment, standart farming operations; sprinkler irrigation, basic fertilization with $350 \mathrm{~kg} / \mathrm{ha}$ of 12-17-17 (N-P2O5-K2O) mineral fertilizer, phytosanitary treatments to meet the normal crop protection requirements were carried out in experiment according to common agrotechnical principles.

Plant samples were taken at physiological maturity in Peanut. In experiment, three leaflets of the second or the third leaf from the apex of the main stem were used for total and active Fe, and chlorophyll analysis. Chlorophyll content of fresh plants leaves were determined by acetone extraction [6]. For total Fe determination, plant samples were dried at $60{ }^{\circ} \mathrm{C}$ in a forced-air oven, ground with agitate mortar and then digested in aqua regia $(1: 3 \mathrm{HNO} / \mathrm{HCl})$. Active Fe content was determined within $2 \mathrm{~h}$ of collecting the samples by cutting the tissue into 1- to 2- mm sections. Two grams of tissue were mixed with $20 \mathrm{~mL}$ of $1 \mathrm{~N} \mathrm{HCl}$, let stand for $24 \mathrm{~h}$ and 
then filtered [7]. In the resulting solutions, total $\mathrm{Fe}$ and active Fe were determined by inductively coupled plasma (ICP) emission spectrometry.

Data were analyzed by standard ANOVA procedures for a randomized complete block design and least significant difference (LSD) at $\mathrm{P}<0.05$ was used.

\section{Results and Discussions}

\subsection{Evaluation of Soil characteristics}

The analytical characteristics of the greenhouse soil used in experiment was shown in Table 1 . As can be seen from the examination of Table 1, upper profile depth of soil $(0-30 \mathrm{~cm})$ used in experiment has a slightly alkaline reaction, high lime content, moderate cation exchange capacity, low organic matter content, low conductivity value and loam texture. In terms of plant nutrient content, soil contains high levels of total nitrogen, low levels of available phosphorus, highly exchangeable potassium, calcium and magnesium, and high levels of available Fe, manganese, zinc and copper. The free lime and HCO3 contents of the soil sample are high. In the lower depth of the soil profile $(30-60 \mathrm{~cm})$, the texture clay loam, $\mathrm{pH}$ value was determined in the moderate alkaline reaction, total nitrogen was at the moderate level, available $\mathrm{Fe}, \mathrm{Mn}$ and $\mathrm{Zn}$ concentration was at the moderate levels. Other parameters are determined as in the upper profile.

Physical and chemical characteristics of field soil studied in the experiment are well within the accepted normal range of agronomic values with the exception of high $\mathrm{CaCO} 3$, free $\mathrm{CaCO} 3$ and high $\mathrm{HCO} 3$ contents. It is seen that there is no significant deficiency in the soil other than phosphorus according to the avaiilable plant nutritional values, especially in terms of Fe content, the test soil contains enough Fe to meet the needs of many culture plants. However, it is expected that the high $\mathrm{CaCO} 3$ and $\mathrm{HCO} 3$ coverage of the test soil will create a significant problem in terms of plant Fe uptake. Fe deficiency problems are frequently encountered in plants under high lime and alkaline soil conditions. Among these, the most important factors that negatively affect the $\mathrm{Fe}$ nutrition of plants are the high $\mathrm{HCO} 3$ content of the soil specific to calcareous soils with high lime coverage. It is seen that these two factors are high in the experimental soil.

Table I. The analytical characteristics of the experimental field soil profile $(0-30 \mathrm{~cm}$ and $30-60 \mathrm{~cm})$

\begin{tabular}{|c|c|c|c|c|}
\hline Parameters & $0-30 \mathrm{~cm}$ & Evaluation & $30-60 \mathrm{~cm}$ & Evaluation \\
\hline Sand, $\%$ & 39,2 & & 40,2 & \\
\hline Silt, \% & 24,3 & Loam texture & 26,6 & Clay Loam texture \\
\hline Clay, \% & 36,5 & & 33,2 & \\
\hline $\mathrm{pH}(1: 2$ water, w:v) & 7,7 & Slightly alkaline & 7,9 & Moderate alkaline \\
\hline $\mathrm{CaCO}_{3}$ (Scheibler), $\%$ & 35 & High calcareous & 36,2 & High calcareous \\
\hline Free $\mathrm{CaCO}_{3}$ (in Saturation extract), \% & 9,4 & High & 9,6 & High \\
\hline Water soluble $\mathrm{HCO}_{3}$ (in Saturation extract), me $\mathrm{L}^{-}$ & 8,5 & High & 8,2 & High \\
\hline Organic matter (Walkley-Black), \% & 1,68 & Low & 1,06 & Low \\
\hline Cation exchange capacity (CEC), $\mathrm{cmol} \mathrm{kg}^{-1}$ & 15 & Moderate & 16,2 & Moderate \\
\hline $\mathrm{EC}, \mathrm{dS} \mathrm{m} \mathrm{m}^{-1} 25^{\circ} \mathrm{C}$ & 0,01 & Low conductuvity & 0,01 & Low conductuvity \\
\hline Total Nitrogen (Kjeldahl), \% & 0.12 & High & 0.09 & Moderate \\
\hline Available Phosphorus (Olsen ext.), $\mathrm{mg} \mathrm{kg}^{-1}$ & 7,2 & Low & 3,7 & Low \\
\hline Exchangeable Potassium (NH4AOc ext.), $\mathrm{mg} \mathrm{kg}^{-}$ & 80 & Medium & 67 & Medium \\
\hline Exchangeable Calcium (NH4AOc ext.), me 100 & 29,4 & High & 30,1 & High \\
\hline Exchangeable Magnesium (NH4AOc ext.), me & 8,4 & High & 7,8 & High \\
\hline Available $\mathrm{Fe}, \mathrm{mg} \mathrm{kg}^{-1}$ & $12^{1}$ & High & $4,5^{1}$ & Moderate \\
\hline Available Manganese, $\mathrm{mg} \mathrm{kg}^{-1}$ & $5,2^{1}$ & High & $2,2^{1}$ & Moderate \\
\hline Available Zinc, $\mathrm{mg} \mathrm{kg}^{-1}$ & $5,2^{1}$ & High & $1,7^{1}$ & Moderate \\
\hline Available Copper, $\mathrm{mg} \mathrm{kg}^{-1}$ & $0,6^{1}$ & Moderate & $0,5^{1}$ & Moderate \\
\hline
\end{tabular}

: DTPA-extractable concentrations

\subsection{Plant Genotype Characteristics}

Average of total chlorophyll, active and total Fe contents and Fe sufficiency levels in 16 Peanut genotypes were presented in Table 2. The differences of peanut genotypes in terms of total chlorophyll, active Fe and total 
Fe contents were found statistically significant. Among the 16 peanut genotypes examined, the total chlorophyll content was determined in the highest ICGV-88463 and Gazipaşa genotypes, and the lowest values in the genotype PI-372317. It is seen that some peanut genotypes show iron deficiency although there is sufficient useful iron in calcareous and slightly alkaline soil (Table 1).

It was visually determined that the differences in total chlorophyll content in the experiment were compatible with the color changes (chlorosis) observed in plants. Peanut genotype PI-372317 leaves showed severe chlorosis. In terms of active and total Fe contents, the highest values were determined in the ICGV-88463 and Gazipaşa genotypes and the lowest values in the PI-372317 genotype. It is reported that BARI-2000 and 96CG005 Peanut genotypes have better ability to tolerate Fe deficiency and have higher iron reductase ability in calcareous soil conditions [8].

Correlations among total chlorophyll, active $\mathrm{Fe}$ and total $\mathrm{Fe}$ content of peanut genotypes are presented in Table 3. Correlations among these three parameters were found significant. However, although there were significant differences between genotypes in terms of total Fe content, it was determined that these differences were partially decreased in terms of active Fe content (Figure 1).

As for Fe nutritional status of peanut genotypes, active Fe content and total chlorophyll content of almost all of the genotypes those have sufficient levels of total Fe (Osmaniye, Gazipaşa, ICGV-88463, NC-7, COM, Florigant, Anamur-K, 88490, PI-346385) appear that they are not high. This supports that the total Fe concentration determined in the plant in Fe nutrition of the peanut plant cannot be an important indicator, and that active $\mathrm{Fe}$ content may be an important parameter in the unavailability of $\mathrm{Fe}$ due to $\mathrm{CaCO} 3$ or $\mathrm{HCO} 3$ in the soil. The differences in Fe use efficiency among plant genotypes reveal the importance of $\mathrm{CaCO} 3$ and $\mathrm{HCO} 3$ resistant gene selection in Peanut farming in calcareous alkaline soils. It is reported that Fe reducing capacity of Peanut roots was directly correlated with the ability of groundnut genotypes grown in calcareous soils [9] Tolerant genotypes reduced $\mathrm{Fe} 3+$ earlier and to a greater extent than the sensitive genotypes [10].

Table II. Average of total chlorophyll, active and total Fe contents and Fe sufficiency levels in 16 Peanut genotypes.

\begin{tabular}{|c|c|c|c|c|c|c|c|c|}
\hline \multirow{2}{*}{$\begin{array}{l}\text { No } \\
1\end{array}$} & \multirow{2}{*}{$\begin{array}{l}\text { Plant Genotype } \\
\text { Osmaniye }\end{array}$} & \multicolumn{2}{|c|}{ Total Chlorophyll, $\mathrm{mg} \mathrm{g}^{-1}$} & \multicolumn{2}{|c|}{ Active $\mathrm{Fe}, \mathrm{mg} \mathrm{kg}^{-1}$} & \multicolumn{2}{|c|}{ Total Fe, $\mathrm{mg} \mathrm{kg}^{-1}$} & \multirow{2}{*}{$\begin{array}{c}\begin{array}{c}\text { Nutritional Fe level in } \\
\text { plant }\end{array} \\
\text { Sufficient }\end{array}$} \\
\hline & & 0.709 & bcd & 65 & $\mathrm{bc}$ & 113 & bcdef & \\
\hline 2 & Gazipasa & 0.937 & $\mathbf{a b}$ & $\mathbf{8 8}$ & ab & 175 & a & Sufficient \\
\hline 3 & ICGV-88463 & 1.058 & $\mathbf{a}$ & 115 & $\mathbf{a}$ & 166 & $\mathbf{a b}$ & Sufficient \\
\hline 4 & NC-7 & 0.460 & de & 50 & $\mathrm{c}$ & 107 & bcdef & Sufficient \\
\hline 5 & GK-3 & 0.505 & cde & 43 & $\mathrm{c}$ & 79 & ef & Deficient \\
\hline 6 & $\mathrm{COM}$ & 0.631 & bcde & 65 & $\mathrm{bc}$ & 142 & abcd & Sufficient \\
\hline 7 & Florigant & 0.633 & bcde & 59 & $\mathrm{bc}$ & 118 & abcdef & Sufficient \\
\hline 8 & Anamur-K & 0.652 & bcde & 65 & $\mathrm{bc}$ & 126 & abcde & Sufficient \\
\hline 9 & 88490 & 0.726 & bcd & 63 & $\mathrm{bc}$ & 151 & $\mathrm{abc}$ & Sufficient \\
\hline 10 & 88398 & 0.683 & bcd & 53 & $\mathrm{c}$ & 97 & cdef & Deficient \\
\hline 11 & Cine & 0.524 & cde & 48 & $\mathrm{c}$ & 89 & def & Deficient \\
\hline 12 & 88172 & 0.415 & de & 42 & $\mathrm{c}$ & 63 & $f$ & Deficient \\
\hline 13 & PI-346385 & 0.803 & $a b c$ & 64 & $\mathrm{bc}$ & 121 & abcdef & Sufficient \\
\hline 14 & Edirne 9P-53 & 0.538 & cde & 43 & $\mathrm{c}$ & 76 & ef & Deficient \\
\hline 15 & Adana-Selection & 0.466 & de & 40 & $\mathrm{c}$ & 86 & def & Deficient \\
\hline 16 & PI-372317 & 0.351 & $\mathrm{e}$ & 48 & & 75 & ef & Deficient \\
\hline \multicolumn{2}{|c|}{ Standart Deviation } & \multicolumn{2}{|l|}{0,1899} & \multicolumn{2}{|l|}{19,3975} & \multicolumn{2}{|l|}{33,8881} & \\
\hline \multicolumn{2}{|c|}{ Standart Error } & \multicolumn{2}{|l|}{0,0475} & \multicolumn{2}{|l|}{4,8494} & \multicolumn{2}{|l|}{8,4720} & \\
\hline \multicolumn{2}{|c|}{ Significancy } & \multicolumn{2}{|l|}{$* *$} & \multicolumn{2}{|l|}{ ** } & \multicolumn{2}{|l|}{$* *$} & \\
\hline
\end{tabular}

**:P>0,01; Means within the same column followed by the same letter do not differ significantly at $k$-ratio=100 (ca $P \leq 0.05$ ). 


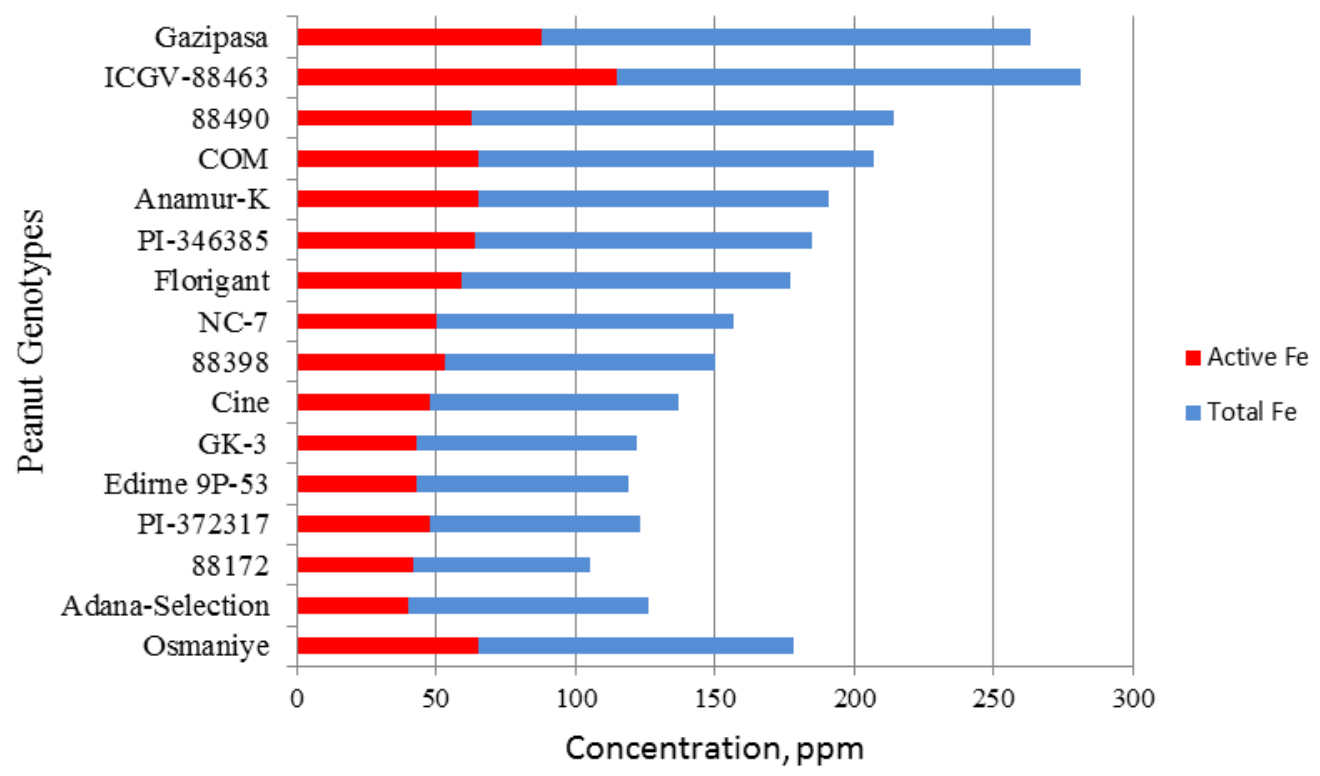

Fig. 1. Active Fe and total Fe contents of 16 Peanut genotypes

Table III. Pearson's correlation cofficient showing relationship among the plant total and active Fe and total chlorophyll contents in Peanut genotypes

\begin{tabular}{lccc}
\hline & Chlorophyll & Active Fe & Total Fe \\
\hline Chlorophyll & 1 & & \\
Active Fe & $0,912^{* *}$ & 1 & 1 \\
Total Fe & $0,862^{* *}$ & $0,867 * *$ & 1 \\
\hline
\end{tabular}

**. Correlation is significant at the 0.01 level (2-tailed).

\section{Conclusion}

In acute and latent Fe deficiencies frequently encountered in plants growing in calcareous and alkaline soils, adaptations of plant genotypes to these conditions are of great importance. Among the genotypes of the peanut plant, there is a wide variation in terms of Fe use efficiency. Among the genotypes examined, Gazipaşa and ICGV-88463 were determined to have higher values in terms of total chlorophyll, active and total Fe contents compared to other genotypes. It has been determined that these genotypes successfully complete their vegetation in a calcareous alkaline soil that creates difficult conditions in terms of Fe nutrition and these are hopeful and suitable genotypes that can be cultured in these conditions. Fe use efficiency for Peanut could be used to screen tolerant Peanut varieties to Fe deficiency. Application of these data in future studies has potential utility within the fields of agro-biodiversity conservation and nutrition of Peanut.

\section{Acknowledgements}

This research was carried out in West Mediterranean Agricultural Research Institute (former Mediterranean Agricultural Research Institute, Antalya) experimental fields in 1997-1998. Author present his thanks and regards to all technical and administral staff for their valuable supports and encouragements at that time period.

\section{References}

[1] Krouma, A., Drevon, J. J., \& Abdelly, C. Genotypic variation of N2-fixing common bean (Phaseolus vulgaris L.) in response to iron deficiency. Journal of plant physiology, 2006, 163(11), 1094-1100.

https://doi.org/10.1016/j.jplph.2005.08.013 
[2] Raut, M.M., More, S.D., Dahale, M.H. Correction of Fe chlorosis in peanut on calcareous vertisols. Annals of Plant Physiology, 1998, 12:1, 85-86.

[3] O-Hara, G.W., Hartzook, A., Bell, R.W., Loneragen, J.F., Barrow, N.J. Differences between Bradyrhizobium strains NC92 and TAL1000 in their nodulation and nitrogen fixation with peanut in Fe deficient soil. Plant and Soil, 1993, 155: 333-336.

https://doi.org/10.1007/BF00025050

[4] Gutschick, V. P. Optimization of specific leaf mass, internal $\mathrm{CO} 2$ concentration, and chlorophyll content in crop canopies. Plant physiology and biochemistry (Paris), 1988, 26(4), 525-537.

[5] Page, A.L., Miller,R.H., Keeney, D.E., Baker, D.E., Ellis, R. and Rhoades, J.D. Methods of soil analysis. Part 2. Chemical and Microbiological Properties (Second edition). 1982, Madison, Wisconsin USA.

[6] Arnon, Daniel I. Copper enzymes in isolated chloroplasts. Polyphenoloxidase in Beta vulgaris. Plant Physiology. 1949, Volume 24, pp. 1-15.

https://doi.org/10.1104/pp.24.1.1

[7] Takkar PN, Kaur NP. HCl method for Fe2+ estimation to resolve Fe chlorosis in plants. Journal of Plant Nutrition, 1984, 7:81-90.

https://doi.org/10.1080/01904168409363176

[8] Akhtar, S., Shahzad, A., Bangash, N., Arshad, M., \& Ahmed, I. Morpho-physiological and genetic diversity of groundnut (Arachis hypogaea L.) genotypes under iron deficiency stress. Pakistan Journal of Agricultural Sciences, 2014, 51(4).

[9] Gao, L., and Y. Shi. Genetic differences in resistance to iron deficiency chlorosis in peanut. J Plant Nutr. 2007, 30:3752.

https://doi.org/10.1080/01904160601054965

[10] Jolley, V.D., D.J. Fairbanks, W.B. Stevens, R.E. Terry, and J.H. Orf. Root iron-reduction capacity for genotypic evaluation of iron efficiency in soybean. J. Plant Nutr., 1992, 15:1679-1690.

https://doi.org/10.1080/01904169209364430 